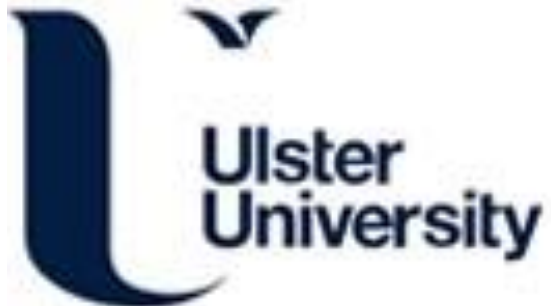

\section{Foreign Residents and Illegal Immigrants in Portugal}

Eaton, M. (1998). Foreign Residents and Illegal Immigrants in Portugal. International Journal of Intercultural Relations, 22(1), 49-66.

Link to publication record in Ulster University Research Portal

\section{Published in:}

International Journal of Intercultural Relations

Publication Status:

Published (in print/issue): 01/01/1998

\section{Document Version}

Publisher's PDF, also known as Version of record

\section{General rights}

Copyright for the publications made accessible via Ulster University's Research Portal is retained by the author(s) and / or other copyright owners and it is a condition of accessing these publications that users recognise and abide by the legal requirements associated with these rights.

\section{Take down policy}

The Research Portal is Ulster University's institutional repository that provides access to Ulster's research outputs. Every effort has been made to ensure that content in the Research Portal does not infringe any person's rights, or applicable UK laws. If you discover content in the Research Portal that you believe breaches copyright or violates any law, please contact pure-support@ulster.ac.uk. 
Int. J. Intercultural Rel. Vol. 22, No. 1, pp. 49-66, 1998

O 1998 Elsevier Science Ltd. All rights reserved

Printed in Great Britain

$0147-1767 / 98 \$ 19.00+0.00$

\author{
PII: S0047-1767(97)00035-7
}

\title{
FOREIGN RESIDENTS AND ILLEGAL IMMIGRANTS IN PORTUGAL
}

\author{
M. EATON* \\ University of Ulster at Coleraine
}

\begin{abstract}
Foreign residents make up a small but thriving and cosmopolitan community in Portugal. Around 121,500 are legally registered but a much larger number have entered an informal economy where Europeans, Africans and South Americans, search for their fortunes. This article spotlights the presence of official registrations, looks at the recent influx of illegals, and examines their respective impacts upon the development of Portugese society. Evidence shows that some immigrant communities are now in a difficult position. Many of them are contributing to the socioeconomic development of Portugal but, at the same time, they are often viewed as inferior groups by the host population. Several of these groups are therefore more likely to be manipulated; prejudice is growing and legal status counts for little. In that situation, the unevenness of discriminatory practices (particularly with respect to education and housing) is discussed, and the need to assist the most exploited sections of the immigrant population is outlined. (C) 1998 Elsevier Science Ltd. All rights reserved
\end{abstract}

KEY WORDS. Immigration, development, discrimination, housing, education, Portugal.

\section{INTRODUCTION}

Immigration is once again one of the European Union's (EU's) most important strategic issues. Public disorder in immigrant communities in France, racist attacks in Italy, and disaffection among former East and West Germans have served to highlight the volatility of Europe's migrant phenomenon. Extensive and continuing levels of population flows into each of the EU member states in the mid-1990s, together with proactive and reactive responses from different governments has meant that the immigrant has become a sensitive political issue. The situation is complicated because the social and economic problems created by recent movements of East European populations (Carter et al., 1993; Fernhout,

* Dr Martin Eaton, Lecturer in European Regional Development, University of Ulster at Coleraine, Northern Ireland BT52 1SA. 
1993) have tended to shroud the significance of illegal immigration through Europe's "back door". Indeed, immigration via the Southern European flank of the EU into Portugal, Spain and Italy, for example, has now reached unprecedented levels (Andall, 1990; Carver, 1990; Campani, 1993; Sole, 1995; King, 1996).

As a case study for immigration, the Iberian Peninsula is important because of its position in the world economic space. Corkill (1993) explains the theoretical processes associated with Portugal's underdevelopment and subsequent attempts to Europeanize its production processes. Inevitably, there will be a demand for cheap labor to help engender this process and it is the immigrant workforce which is being increasingly utilized. Moreover, Portugal harbors labor shortfalls in certain sectors of activity, and is a country with established immigrant communities within which new arrivals can readily settle (Eaton, 1993, 1996). In the international division of labor (Sassen, 1988), the already low wages paid to Portugese workers in an EU context can be undercut still further by the employment of illegal immigrants. As a recipe for modernization and continued capital accumulation, Portugal is therefore well placed to become an export processing zone for factory produced commodities (Eaton, 1990). Moreover, it is a country making full use of those immigrants who are: "seeking to sell their labor power for a wage" (Miles \& Satzewich, 1990, p. 334).

This type of migration is, however, a process fraught with difficulties and the question of illegal immigrants, their civil rights and their contribution to the Portugese economy have recently been spotlighted. It is thought, for example, that as many as 50,000 out of the 100,000 Africans from the former colonies now conservatively estimated (EIU, 1993a) to be living in Portugal, are doing so illegally. Furthermore, of the remaining 50,000 , many have still to attain full Portugese citizenship. This article, therefore, examines the different types of foreign residents, illegal immigrants and their family dependants. We are concerned with the readily observable, but poorly documented influx of non-Portugese nationals and we will specifically examine the processes that have turned Portugal, formerly a country of net out migration, into a country of net in migration.

However, before that we must acknowledge that the study is dealing with a grey area in Portugese society since there are both official and unofficial factors to consider. Accurate figures on elements that are clandestine are difficult to assess; scientific methodology is diminished, and much of the material is drawn from informal discussion with immigrant elements. As a result of these factors the text is devoted to speculation built around these grey areas. Our central theme surrounds the response from the Portugese themselves, since participant observation suggests that Portugese society is a culturally assimilated community. On the other hand, there are those who argue that the Portugese population is one of the most discriminatory in the whole of the EU. In that apparently 
contradictory situation, this work focuses upon education and housing issues, and attempts a realistic assessment of the present position. At the same time, we acknowledge that there has been little research-except for Céu Esteves (1991) - into this burgeoning sector of Portugese life. As a result, this article takes a minor but nevertheless important step into the question of Portugese immigration.

\section{TYPES OF PORTUGESE IMMIGRANT}

There are several different types of ethnic immigrant in Portugal ranging from the North European communities to the Africans, and onto the North and the South Americans. Some are officially registered foreign residents; others are clandestine arrivals. All have a part to play in the development of the Portugese economy and yet little of their overall contribution is fully understood by the host community.

Hence, our first misconception. It would be misleading to speculate on the legal position of immigrants in Portugal on the basis of origin. To assume that if you are a Caucasian North European then you are operating within the law, and if you are a colored African then you are illegal and you are not operating within the law, is untrue. In the Algarve (Southern Portugal), for example, there were over 7,700 European Union residents officially registered in 1991. Of those, Table 1 shows that almost 4,600 (over one third) were British (INE, 1992, p. 182). However, it is known that 20,000 other Britons now living in the south of Portugal are doing so illegally (Cal, 1986) and they are the most visible foreign community in that region. The British live in a large and unregulated economy which is serviced by its own doctors, estate agents, bar owners, plumbers, swimming pool cleaners, and in some cases, its own British schools and newspapers. The reason for this illegal presence is because many people are reluctant to pay British taxes and given the administrative process of taking up legal residence in their chosen country, few decide to do so. As a result, they do not pay Portugese taxes and they are therefore exploiting a country that

TABLE 1

Breakdown of Legally Resident Foreigners in Faro, 1991

\begin{tabular}{lcccccc}
\hline County & $\begin{array}{c}\text { Total } \\
(\%)\end{array}$ & $\begin{array}{c}\text { Cape Verdian } \\
(\%)\end{array}$ & $\begin{array}{c}\text { German } \\
(\%)\end{array}$ & $\begin{array}{c}\text { British } \\
(\%)\end{array}$ & $\begin{array}{c}\text { Dutch } \\
(\%)\end{array}$ & $\begin{array}{c}\text { Rest } \\
(\%)\end{array}$ \\
\hline Faro & $\begin{array}{c}13,048 \\
(100)\end{array}$ & $\begin{array}{c}1,754 \\
(13)\end{array}$ & $\begin{array}{c}1,235 \\
(9)\end{array}$ & $\begin{array}{c}4,599 \\
(35)\end{array}$ & $\begin{array}{c}811 \\
(6)\end{array}$ & $\begin{array}{c}4,649 \\
(36)\end{array}$ \\
\hline
\end{tabular}

Source: INE (1992, pp. 182-183). 
is generally considered one of the poorest in the EU. Concerted action against the British has still to be taken; most probably because of fears of upsetting the international tourism industry whose effects on local Algarvian communities are often considerable (Lewis \& Williams, 1991; EIU, 1993b). The illegal British presence is therefore publicly condoned and allowed to continue.

Traditionally, Portugal has exported emigrants (Miles \& Singer-Kérel, 1991). In 1988, for example, some 18,300 migrants left Portugal to takeup residence in another country. Europe and North America dominated the out migration flows, with the U.S.A., Canada, France and Switzerland being the favored destinations (INE, 1989, p. 206). Official levels of immigration, on the other hand, have tended to be smaller. In 1992, Africa (with Angola, Guinea-Bissau and Cape Verde Islands dominating), and the South Americas (Brazil) were the main sources of almost $13,750 \mathrm{immi-}$ grants for Portugal. However, these official inward figures (INE, 1993a, pp. 168-169) severely underestimate the real levels. Immigration from Angola, Mozambique and from the Cape Verde Islands is much greater than that officially recorded. The main reason being that the living conditions affecting mobility in each of those countries have changed for the worse since the Portugese Revolutionary period of 1974 1975. Both Angola and Mozambique have endured bloody civil wars and the Cape Verde Islands have undergone a Socialist revolution--producing theorctically classical push factors for many emigrants.

Moreover, the traditional illegal migration trails from rural poverty in parts of the Portugese interior to urban affluence in France (Cónim \& Carrilho, 1989) are now being replicated in Portugal. However, this time, the immigrants are usually colored, often native or second language Portugese speakers, and invariably individuals from former colonial outposts. Most of them do the work in the mid-1990s (construction, manufacturing. services industry, etc.) that the Portugese refuse to do themselves in their own country but which, ironically, they had travelled to find in the early 1970 s in Northern Europe. Portugal's transformation from a country of emigration into one of immigration coincides with a recent period in European integration. This is a phase that allows many newer immigrants a chance to gain a foothold in the European Union. Subsequent onward movement (once official registration is attained) is now influenced by the Schengen Agreement', but ultimately the immigrant will be allowed to

\footnotetext{
'The Schengen Agreement allows for the gradual abolition of border checks and freedom of passage between the frontiers of Belgium, France. Germany, Luxembourg. The Netherlands. Italy, Spain and Portugal (see Fontaine, 1992, p. 14).

'One should also remember that freedom of movement for Portugcse labor was a special condition of the country's aceession to the EU in 1986 and that this provision was no longer effcctively applied after 1 January 1993 (see Werth, 1989).
} 
travel throughout the European Union ${ }^{2}$. In time, that immigrant will also be able to move unimpeded throughout the amalgamated space of the EU and the European Free Trade Association countries-in the so-called European Economic Area (DTI, 1992). The economic rewards, therefore, over a longer period mean that the potentials outweigh the short-term difficulties for many of these immigrant groups. It also helps to explain risk overriding fear as a prime motivational factor in the Portugese immigration equation.

There are, nevertheless, problems associated with this more recent stepwise migration trail. Despite the African's role in bringing democracy to Portugal (they helped in destabilizing the Salazar/Caetano dictatorships through colonial warfare in the early 1970s, for example), and despite their help in the physical development of the country, few are recognized as nationalized Portugese citizens. Many do not have welfare rights nor the right to vote in elections, indeed, many have no basic human rights of any kind. Several factors account for this position. First, residence permits ${ }^{3}$ are only available to persons who have lived in Portugal for six years. Secondly, they must have a job and, thirdly, they must be considered by the Portugese authorities to be "socially adaptable". Most of the illegal immigrants fail to satisfy any or all of these requirements. Yet at the same time, the colored African immigrants in employment are often acknowledged as diligent workers, willing to do any job, no matter how dangerous, demanded of them. Observation of immigrant laborers in the South of the country, working for up to fourteen hours a day, seven days a week, in high summer temperatures would echo this feeling. The laborers were noted constructing tourist apartment blocks at a rate of one storey per week, with no safety equipment, little apparent supervision, and primitive living conditions. As we shall see, it is this precarious lifestyle that lays many of them open to prejudice, manipulation and exploitation.

\section{FOREIGN RESIDENTS}

Table 2 illustrates the official levels of immigration into Portugal. In 1992, there was a total of just over 121,500 legally registered foreigners; of which the largest group were from the Cape Verde Islands (a community

\footnotetext{
${ }^{3}$ In 1986 when the (white, English) author applied for his residence permit, he satisfied neither of the first two criteria and has no idea whether nor how he might have been judged "socially adaptable". Significantly, the said permit was acquired with only minor inconvenience (a waiting period of about four months) from a relatively disinterested foreigner's service in Coimbra, Central Portugal. Again, informal conversation with colored immigrants suggests that even the lucky ones have to wait for much longer periods. The evidence is clearly circumstantial, but the suspicion of discrimination on the grounds of race does remain.
} 
TABLE 2

Legally Resident Foreigners in Portugal, 1989-1992

\begin{tabular}{|c|c|c|c|}
\hline \multirow[b]{2}{*}{ Country of origin } & \multicolumn{2}{|c|}{ Total } & \multirow{2}{*}{$\frac{\% \text { change }}{1989-1992}$} \\
\hline & 1989 & 1992 & \\
\hline Cape Verde Islands & 27,972 & 31,127 & $+11 \%$ \\
\hline Angola & 4,842 & 6.601 & $+36 \%$ \\
\hline Guinea-Bissau & 3,447 & 5,808 & $+68 \%$ \\
\hline Mozambique & 2,980 & 3,574 & $+20 \%$ \\
\hline Saint Thomas Island & 1,873 & 2,519 & $+34 \%$ \\
\hline Other African Countries & 1,675 & 2,408 & $+44 \%$ \\
\hline United States of America & 6,438 & 7,321 & $+14 \%$ \\
\hline Canada & 2,092 & 2,109 & $+1 \%$ \\
\hline Other North American Countries & 207 & NA & - \\
\hline Brazil & 10,520 & 14,048 & $+33 \%$ \\
\hline Venezuela & 4,886 & 4,910 & $+0.5 \%$ \\
\hline Other South American Countries & 532 & 1,002 & $+88 \%$ \\
\hline Asian Countries & 3,741 & 4,769 & $+27 \%$ \\
\hline The United Kingdom & 7,761 & 9,284 & $+20 \%$ \\
\hline Spain & 7,294 & 7,734 & $+6 \%$ \\
\hline Germany & 4,482 & 5,404 & $+21 \%$ \\
\hline France & 3,019 & 3,674 & $+22 \%$ \\
\hline The Netherlands & 1,670 & 2,010 & $+20 \%$ \\
\hline Other European Countries & 5,021 & 5,390 & $+7 \%$ \\
\hline Oceanic Countries & 347 & 391 & $+13 \%$ \\
\hline Others (with dual-/without nationality) & 212 & 230 & $+8 \%$ \\
\hline Total for Portugal ${ }^{1}$ & 101,011 & 121,513 & $+20 \%$ \\
\hline
\end{tabular}

${ }^{1}$ Total includes foreigners living in the Azores and Madeira.

Source: INE (1990a, p. 257; 1993a, p. 182).

over 31,100 and representing one quarter of the total). In second place, came the Brazilians (14,000), third were the British (9,300), and fourth, the Spanish (at just over 7,700 registrations). The first figure represents those Cape Verdians who have attained official registration status. There are, however, many thousands more who have yet to appear on the Government's "books". Table 2 also shows that the size of the foreign community in Portugal increased by $20 \%$ between 1989-1992. Most of the newer immigrants originated from the former African colonies (of 
Guinea-Bissau and Angola), from the EU (France and Germany), and from Brazil. In relative terms, colored Africans formed around 0.5 per cent of the overall Portugese population. As many as 60 per cent of those were from the Cape Verde Islands. Brookshaw (1992) suggests that the Cape Verdian influx is a legacy of the economic deprivation previously orchestrated by the Portugese colonists. However, and even with the onset of independence and the establishment of a revolutionary Socialist Government this has done little to change general living conditions on the islands. It is, therefore, a combination of socioeconomic difficulties that continues to force out many individuals.

The distribution of foreign residents in Portugal is shown in Figure 1. Lisbon had the largest concentration of foreigners in 1991 with almost

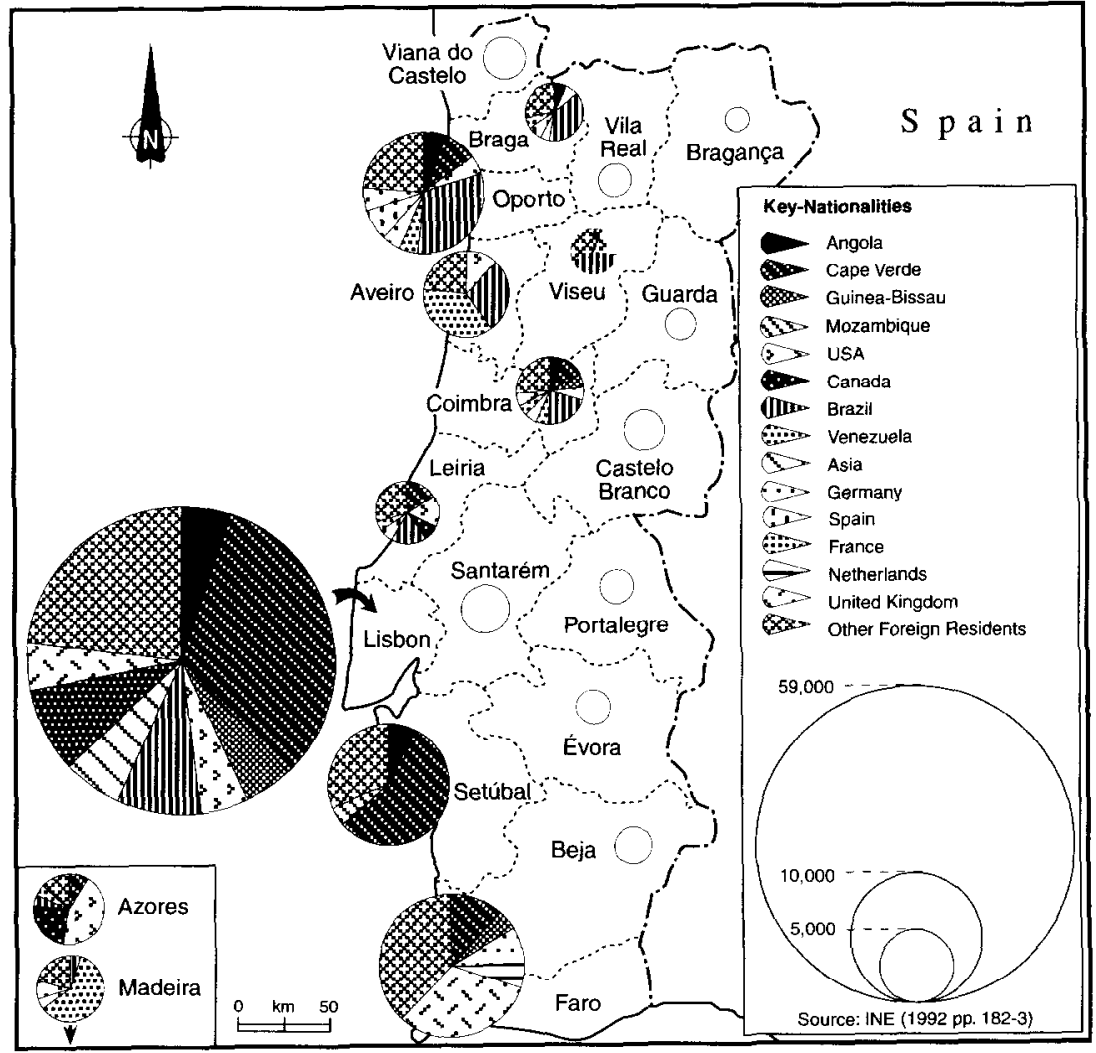

Note: Only counties with foreign residents totalling more than 1,000 are sub-divided by nationality

FIGURE 1. Distribution of Foreign Residents in Portugal, 1991. 
$52 \%$ of the total number, followed by the counties of Faro $(11.5 \%)$ and Setúbal $(9.5 \%)$. Lisbon also houses the single largest community of foreigners (some 19,600 from the Cape Verde Islands). While these figures are not entirely accurate (because they take no account of illegals) they do reflect the general patterns associated with in migration to Portugal, and can be taken as a guide to the location and impact of many of the immigrants. Areas along the coastal littoral margin covering Lisbon, the Algarve and in the industrialized cities of Setubal, Oporto and the industrializing centers of Aveiro and Braga dominate. Job opportunities are invariably greater and living conditions are relatively better (Naylon, 1987; Wise, 1990; Pimpão, 1991) in these zones and they will inevitably attract many immigrants ${ }^{4}$. Based on these comments it is therefore fair to say that legal immigration has become an influential and intractable issue for Portugal.

\section{CLANDESTINE IMMIGRATION}

To backtrack a little, slavery was abolished in Portugal in 1836, although it took another fifty years to legally enforce its prohibition. Portugal's link with Africa is historic; the great maritime discoverers colonized the continent more than 550 years ago (Wallis, 1986) and the Portugese were thought to be the first modern Europeans to set a foot in territories which are now Angola and Mozambique. Their mission of spreading the Catholic and Christian faith, while exploiting gold, spice and human resource riches, some would say, made them latter-day economic pirates.

Despite widely welcomed decolonization, piratism of human beings still takes place. Although no-one knows the full extent of illegal migration into Portugal today, nor the absolute levels of exploitation that the African immigrants, in particular, are subjected to. Press articles on female slaves in Portugal have surfaced (Rosado, 1990; Joliffe, 1990a) and there was a report circulating which claimed to have exposed a "slave" labor scheme (Joliffe, 1990b). This scheme is a double-edged story worthy of repetition. Many Africans, mainly Angolans, were involved. An undercover Portugese journalist posing as an employer succeded in "buying" fiftecn Africans to work as builder's laborers for the fee of $£ 1$ per hour; less than half the statutory rate in the construction industry. In the scheme, the only condition the "buyer" had to meet was the provision of a blanket and a place to sleep for each of his/her workers. Their wages were paid to

\footnotetext{
${ }^{4}$ Evidence in support of this continuing trend can be seen in INE's (1993a, pp. 178-179) data for 1992. Of some 12,500 permanent immigrants registering, almost three-quarters $(9,300)$ settled in the Lisbon and Tagus Vallcy region. In turn, 8,000 of those settled in the metropolitan area of Lisbon with a further 1,000 in the Setúbal peninsula.
} 
intermediaries who would often keep individual workers' passports as security against desertion. Estimates on the numbers involved are vague, but it is thought that there were 15,000 Africans working illegally under these informal conditions in Lisbon alone. This network of slave-wage laborers is often controlled by Portugese University students (usually African scholarship holders from the former colonies). They see it as a way of making extra money for themselves. Moreover, they see it increasingly as helping youths evade forced conscription into the Angolan army at home. Known colloquially as the "Freedom Train", the migration path starts in the underground economy of Luanda with the purchase of an expensive and false passport. When the migrants arrive at Lisbon's international airport, they are met by intermediaries who provide an address to guarantee entry to Portugal on a tourist visa for three months. These workers are then taken to live in densely-populated shanty towns on the outskirts of the capital. They are carefully hidden until the agent sells them, either to factory owners or building companies in Lisbon, in Northern Portugal or the Algarve. Those workers who were interviewed said that the intermediaries would often disappear with their wages. Most laborers arrived in Portugal with few possessions and employers usually gave credit for the first month. Of course, if the agent does disappear the worker immediately becomes indebted to his/her employer and a downward spiral of debt becomes inevitable. To add to their difficulties these illegals live in fear of being stopped by the police and deported. Hence, they very quickly risk becoming captives in their work environment and isolated from the wider Portugese society such that their vulnerability is extremely acute.

In fairness, many of the men who were interviewed stated that they preferred having a job. Several used the expression "semi-slavery", and few wanted to fight a civil war in Angola. Most indicated that the small wages they receive in Portugal could be converted into relative riches when sent back home. Indeed, it was this economic motivation that had encouraged many more Africans from the Cape Verde Islands, GuineaBissau, and Senegal to join the trail. Consequently, a better standard of life in Portugal is a tangible element for many migrants to grasp. However, this double-edged example is also a classical case of dependency on illegal labor migration, for both personal and familial development.

\section{VIOLENCE AGAINST IMMIGRANTS}

In contrast to the general situation in Western Europe, and the national situations in France (Webster, 1991), the United Kingdom (Keith, 1987), Italy (Economist, 1990) and Germany (Paterson \& Payne, 1991), physical violence against African immigrants in Portugal is rare. More recently, however, there have been some isolated outbreaks of violence involving 
small, radical groups and immigrants in Lisbon and Oporto. In June 1995, a Portugese national of Cape Verdian descent was killed and eleven others injured in the worst incident to date. In an apparently coordinated assault up to fifty "skinheads" attacked a bar frequented by colored immigrants in the Bairro Alto district of downtown Lisbon (Heeren, 1995a). Ironically, this attack came the day after Portugal's National Day, which had been formally designated as "Dia da Raça"-Day of the Races - a day dedicated to Portugal's: "tradition of tolerance and hospitality" (Heeren, 1995b). In playing down their knowledge of racial violence many Portugese promote a reserved image. That humility is reflected in the received impression that the Portugese are a peaceful nation. Kaplan (1991, p. 168) considers that: "Portugal lives easily with thousands of African and mixedrace immigrants". Indeed, this would be the view of the person in the street (Cal, 1988); their tolerance borne out of several centuries of crosscultural assimilation and cooperation.

Despite this idealism, racial discrimination by the host population does manifest itself. The European Value Systems Study Group in 1992, for example, ranked Portugal first in a list of general intolerance towards minority groups. With respect to neighbors of a different race living next door, some 15 per cent of the Portugese interviewed objected. As for overt racism in the EU the Portugese came second only to the Belgians (Rosenbaum, 1992). This is revealing evidence because collective intolerance is often translated into discrimination in important areas of the host society such as housing and education.

\section{DISCRIMINATION IN EDUCATION}

For Cape Verdians, Portugese is their official language but children learn Creole first; a difficult proposition in itself since there are claims that even in a small population of 350,000 islanders, up to 50 per cent are either illiterate or semi-literate (Brookshaw, 1992). This makes it doubly difficult for Cape Verdian children if they have migrated with their parents and are entering Portugal's educational system for the first time. They struggle to understand and to be understood, and the same applies to their Portugese teachers. There is also a danger with the children living in an isolated community that they may become alienated from the wider society. They may also lack motivation when faced with the difficulties of school-leaving and first job-seeking. In fairness, these are genuine problems experienced by immigrant children not only in Portugal (Saint-Maurice \& Guerra, 1988), but throughout western Europe (Chisholm \& Moorehead, 1989).

There are some new initiatives to help immigrant children in Portugal. For example, classes are being made smaller to provide for closer teaching practices, the under fives have been targeted, extra lessons have been laid on to help pupils catch up, and older children are taught in special, 
out-of-school-time groups. However, only the tip of the iceberg is being reached; many more children fall behind in their studies and others lose interest and this can quickly degenerate into illiteracy. Indeed, evidence (Anon., 1991) suggests that it is Cape Verdian and Saint Thomas Island children that have the highest Primary School dropout rates in Portugal. Failure levels of 60 per cent and 35 per cent, respectively, have been recorded, and the measures outlined above are showing few signs of improving the local predicament for some of the immigrant children.

A major reassessment of those initiatives is clearly needed because the reasons for failure are deep-rooted. These types of marginalized immigrant-children are easily marketable (i.e., cheap), and they will often have their education neglected in favor of finding work and hence tangible remuneration for their family when circumstance and neglect dictate. Here again, the controlling influence of capital in the form of construction companies or factories exerts itself. Indeed, the shadowy underworld of these enterprises makes it difficult for the Portugese Labor Department to penetrate, thus allowing the conditions for the exploitation of immigrants and their children to flourish (Williams, 1992).

\section{DISCRIMINATION IN HOUSING}

Portugal suffers at a national scale from a housing crisis. The two main symptoms are a shortage of new homes and a poor quality of existing houses. These problems are compounded among disadvantaged groups and have led to spatial concentrations of deprivation in certain parts of Portugal. Most of the illegal immigrant workers, for example, live in the surrounding areas of major Portugese towns, or in the rundown inner city and outer-suburban areas of Lisbon. The proliferation of shanty towns in districts such as Amadora, Areeiro, Benfica, Chelas and Damaia around the capital have their roots in the bairros clandestinos identified in the 1960s. A literal translation of a bairro is a suburb but the label has become synonymous with a district comprising illegal and informal dwellings. Many of these houses, which people thought would be temporary dwellings in the 1960s, are now established communities in Portugal (Cardoso \& Pimenta, 1989).

In 1975 there was a large immigration into Portugal of retornados. Some 800,000 displaced ex-colonials were repatriated and while many were able to manage themselves successfully within mainstream Portugese society (Pena Pires, 1987, 1990; Saint-Maurice \& Pena Pires, 1989), untold numbers were forced into temporary dwelling in shanties close to the international airport. Little is known of what came of them. However, many African immigrant communities have now taken over these slum areas with most still exhibiting typical features; shacks made from timber and corrugated iron, chronic overcrowding, poor sanitation, low levels of 
infrastructure. Current estimates suggest that approximately 170,000 people live in some 38,000 shanty dwellings in Lisbon with new shacks springing up at a rate of thirty each week (Newberry, 1994; Sworder, 1994). Not surprisingly, the internal pressures within this burgeoning environment have given rise to many social problems, including drugs, alcoholism, and prostitution. From participant observation of these shanty towns it is clear that dissatisfaction with the personal situation in which the immigrants have found themselves is rife. This contributes to the building of tensions within a family group and, in turn, within the immediate community. Sometimes, that dissatisfaction manifests itself in domestic violence.

Given these factors, bairros de lata--quite literally "tin can towns"-have actually been viewed by the Portugese authorities as a partial solution to the housing problem. This is because to buy or rent a house in Portugal's major cities is often exorbitant for well-paid professionals, let alone for low-paid African workers. Many of the poorer (illegal) elements have, therefore, been forced to build and/or expand shanty settlements on Lisbon's council owned land. In response, a number of local councils have turned a blind eye to their growing presence. The authorities, therefore, have tacitly accepted the proposition that any shelter for immigrants is better than none at all.

A second partial solution to Portugal's housing shortage, has been the suggestion of increased use of existing council housing (Reis \& Passos, 1991). The first problem with this is that much of the council house stock is dilapidated. The second problem is that the waiting lists for such homes are now so long that they have been closed and newcomers are not being added to them. Lisbon's Metropolitan Council (LMC) is trying to tackle the problem. LMC built 10,500 new houses in 1989 (INE, 1990b, p. 57) and is planning to build 10,000 new houses over each of the next five years. However, this is unlikely to satisty the current, let alone the growing demand among Lisbon's inhabitants. Moreover, of those council houses in existence, many are rundown and empty; particularly blighted are the areas of Campolide, Carnide and Marvila. Those houses that are not squatted in, are left to rot. At the very least they can be called slums and are often the physical interfaces between the poverty-stricken immigrant and mainstream Portugese society. The shanties are also embarrassing interfaces providing evidence of the presence of ethnic minorities (with their own basic human rights) living within a democratized and swiftly modernizing EU country.

Many African immigrants have responded to this difficult situation by using skills learned on the construction sites to build houses for themselves. In a number of cases, local councils have actually given the immigrants land and provided a basic level of service infrastructure within which new buildings can be constructed. These are, however, the exceptions rather than the rule. Current estimates suggest that there is a shortage of 800,000 
new homes throughout Portugal and to keep up with the demand 130,000 new homes will have to be built each year during the 1990s. The National Institute for Habitation is responsible for alleviating the situation and is planning to build just 70,000 per annum. That official shortfall of around 60,000 homes means as casas clandestinas (illegal housing) are a second intractable problem for Portugal linked inextricably to the first-illegal immigration. In these circumstances, poverty based on this limited provision of shelter is set to continue. Indeed, recent figures suggest that the shortfall may be even greater because INE (1993b, p. 20) reports that only around 30,000 residential buildings were completed between 19911992. The housing crisis, therefore, may actually be deteriorating still further.

\section{RACIAL DISCRIMINATION}

In atheoretical terms, it takes two sides to create racism; racial discrimination, on the other hand, is normally controlled by the ruling majority and, in turn, the majority can create a climate where racism against the minority is fostered. In our case study, Portugese nationals hold sway over a small, but increasingly important foreign community. In interviews with the author, many immigrants complained of being rejected for state housing, being despised as a single colored parent, or considered inferior on the perceived grounds that they are foreign and/or black. Many suggest feelings of informal segregation when travelling on public transport. Portugese nationals, for example, will only sit in an empty seat next to the immigrant when there is no other choice. In fairness, and on the issue of housing, Lisbon Metropolitan Council denies that there is discrimination in the way it allocates houses. The criterion they use is the waiting list and those who have been waiting the longest are rehoused first, whether they are African, South American or Portugese.

Clearly, this is a difficult situation but one that needs to be set in context. At the national level, the African immigrant population is a negligible element accounting for between 0.5 and $1 \%$ of the total Portugese population of almost ten million. Only when these immigrants congregate together in significant numbers in local areas do they come to be perceived as a threat. In that situation, so long as they can be contained in shanty towns or on construction sites then they are generally tolerated by the host community. As mentioned previously, the average person believes that Portugese society accepts the immigrant influence and that the conflicts have been exaggerated. They point to the successes whereby a small proportion (7\%-INE, 1992, p. 187) of the economically active immigrants registered in Portugal and coming from Africa have professional skills. Collectively, these immigrants are considered integral to the successful 
development of the country and as individuals many have assimilated themselves without too many difficulties (Lamb, 1995).

\section{CONCLUDING DISCUSSION}

On the basis of this examination of the role of the immigrant in Portugal we are left with a series of questions. Is discrimination genuine, as it seems, or is the perception one of false persecution (on the part of the African communities), and/or gross misrepresentation (on the part of the Portugese)? Have things really changed since the dark days of the early slave trade or is history merely repeating itself? Is racism emerging as a real issue, or is it being brushed under the carpet? It is a muddled picture, partly because some foreign residents have fared better than others. A number of African immigrants have fulfilled their personal ambitions and those achievements should not be ignored when the authorities seek to denigrate the less successful efforts of a majority of illegal immigrants. Who is to say that given time, money, cooperation, and opportunity that the illegal immigrants will not improve their individual positions nor those of their immediate families?

What is clear from this investigation, is that the Portugese Government neither condones nor condemns the presence of illegal immigrants in Portugal. The authorities monitor their communities closely, willing to reap the benefits that their collective laboring skills bring. But being quick to punish those individuals reduced (often by difficult personal circumstances) to prostitution, gambling, drug-pushing and/or profiteering. Punishment reflects the position held by the Immigration Service (IS). The Portugese IS claims that when irregularities in an immigrant's papers are found then they try to persuade the person to leave Portugal ... voluntarily! Deportation is considered a last resort and the figures seem to bear this out. In 1990, 250 people were ejected when detected. In theory, there is little chance of escaping from state bureaucracy that decrees that all the Portugese population must possess some form of identification. For nationals this takes the form of an identity document (ID) and this has to be produced for tasks as diverse as getting a place at school to cashing a cheque in a bank. Without an ID, an immigrant can be deported and yet this low figure of 250 deportations can be viewed in a number of ways. It can be argued that the police have neither the time, ability, nor inclination to pursue illegals. It could be that the network of safe houses in the shanty towns is too good. Alternatively, it might be that the Portugese Government privately considers the illegals to be a positive element in their society.

Earlier, Kaplan (1991) described Portugal as having an easy relationship with the African immigrants and to some extent this is true. It is easy for the Portugese because illegals are now a vital $\operatorname{cog}$ in the development of 
the country; a more than useful labor force, one with few financial strains on the welfare system, and a community which is relatively law-abiding. It is also easy in the sense that the Portugese can control the level of discrimination against immigrants. The situation is neatly summed up by one Councillor for Housing in Lisbon who has said that the illegals: "represent an ironic situation-because they are helping to build this city, but they don't have houses to live in". The size of this predicament makes it one of the most urgent problems for the Portugese Government to solve. Furthermore, the immigrant groups because of their developmental contribution deserve to be treated more sympathetically by both the Portugese authorities and the population at large (Leitão \& Correia, 1991). Portugal is not a: "structurally racist society" (Rex, 1988), but most of the ethnic communities (especially those in Lisbon) are at a socioeconomic disadvantage (particularly with respect to housing and education).

One hesitates to suggest that the wage laborers identified earlier in this article can be labelled as "new slaves" or "unfree labor" (Cohen, 1987; Miles, 1987) because their position in Portugese society is relative. They are definable as informally contracted wage laborers, and as such, perform in a largely "hidden" capacity in the Portugese labor market. However, the accusation of incipient slavery is inaccurate because many immigrants tacitly accept their work conditions, satisfied with the remittance value of their wages and safeguarded in the shanty towns away from the generally non-confrontational Portugese authorities. Again, the position of the illegals is not clear-cut, nor is it likely to change. Indeed, this article may have raised more questions than it has answered. Moreover, and what remains, is the fact that immigration represents an entrenched dilemma for Portugal, it is intractable and will not simply go away. Ergo, the period running into the twenty-first century will be an extremely challenging one for the Portugese State. Increasingly, it will find itself having to maintain control of its growing population of both legal and illegal foreigners. Portugal will have to solve the education and housing crises among its immigrants, and it will have to try to integrate its overseas population still further.

\section{REFERENCES}

Andall, J. (1990). New migrants, old conflicts: The recent immigration to Italy. The Italianist, 10, 151-174.

Anon. (1991). Minority results. Anglo Portugese News, 1642, 4.

Brookshaw, D. (1992). Islands apart: Tradition and transition. Index on Censorship, 6, 13-14.

Cal, M. de la (1986). Crackdown planned on Algarve foreigners. The Times, 18 September, 11.

Cal, M. de la (1988). Portugal. London: Collins. 
Campani, G. (1993). Immigration and racism in southern Europe: the Italian case. Ethnic and Racial Studies, 16, 3, 507-535.

Cardoso, A., \& Pimenta, M. (1989). A pobreza nos bairros degradados de Lisboa: Alguns elementos de caracterização. Sociedade e Território, 10/11, 13-24.

Carter, F., et al. (1993). International migration between east and west Europe. Ethnic and Racial Studies, 16, 3, 467-491.

Carver, R. (1990). Back door to El Dorado. The Daily Telegraph, 5 May, 24-32.

Céu Esteves, M. do (1991). Portugal. País de Imigração. Lisboa: IED, Caderno 22.

Chisholm, A., \& Moorehead, C. (1989). Migrant children, France. In C. Moorehead (Ed.), Betrayal: Child exploitation in today's world. London: Barrie and Jenkins, $130-142$.

Cohen, R. (1987). The new helots: Migrants in the international division of labour. Aldershot: Gower.

Cónim, C., \& Carrilho, M. J. (1989). Situação demografica e perspectivas de evolução: Portugal, 1960-2000. Lisboa: IED.

Corkill, D. (1993). The Portugese economy since 1974. Edinburgh: University Press.

Department of Trade and Industry (1992). The European Economic Area. London: DTI.

Eaton, M. (1990). Central Portugal's textile industry: Depression or recovery on the road to international production? Iberian Studies, $19,1 \& 2,95-112$.

Eaton, M. (1993). Os negros em Portugal. Ethnic and Racial Studies, 16, 3, 536 562.

Eaton, M. (1996). Résidents étrangers et immigrés en situation irrégulière au Portugal. Revue Europeenne des Migrations Internationales, 12, 1, 203-212.

Economist (1990). Italy: Gateway to Europe. The Economist Newspaper, 28 April, 65-66.

Economist Intelligence Unit (1993a). Portugal. EIU Country Profile 1993/94. EIU: London.

Economist Intelligence Unit (1993b). Portugal. EIU International Tourism Reports, I. 23-42.

Fernhout, R. (1993). Europe 1993 and its refugees. Ethnic and Racial Studies, 16 , 3, 492-506.

Fontaine, P. (1992). Europe in ten lessons. Luxembourg: CoECs.

Heeren, H. (1995a). Racial violence by skinhead gang in Lisbon. Anglo-Portugese News, $1829,3$.

Heeren, H. (1995b). Police suspect that Lisbon skinhead attack was deliberately planned. Anglo-Portugese News, 1830, 2.

Instituto Nacional de Estatística. (1989). Estatísticas demográficas, continente, Açores e Madeira, 1988. Lisboa: INE.

INE (1990a). Estatisticas demográficas, 1989. Lisboa: INE.

INE (1990b). Estatísticas da construção e da habitacão, continente, Açores e Madeira, 1989. Lisboa: INE.

INE (1992). Estatisticas demográficas, 1991. Lisboa: INE.

INE (1993a). Estatísticas demográficas, 1992. Lisboa: INE.

INE (1993b). Portugal em numeros, 1992. Lisboa: INE.

Joliffe, J. (1990a). Portugal outraged by Angolan girls decade of "slavery". The Sunday Times, 10 June, 1. 
Joliffe, J. (1990b). Angolans work as Portugal's "slaves". The Guardian, (undated).

Kaplan, M. (1991). The Portugese, the land and its people. London: Viking.

Keith, M. (1987). "Something happened": The problems of explaining the 1980 and 1981 riots in British cities. In P. Jackson (Ed.), Race and racism: Essays in social geography. London: Allen and Unwin, 275-303.

King, R. (1996). Migration and development in the Mediterranean region. Geography, 81, 1, 3-14.

Lamb, C. (1995). Brazilians colonise Portugal. Sunday Times, 29 October.

Leitão, J., \& Correia, M. C. (1991). Integração necessária das minorias étnicas. Expresso, 28 Setembro, A9.

Lewis, J., \& Williams, A. (1991). Portugal: Market segmentation and regional specialisation. In A. Williams \& G. Shaw (Eds.), Tourism and economic development: Western European experiences, 2nd Ed. London: Belhaven. 107-129.

Miles, R. (1987). Capitalism and unfree labour: Anomaly or necessity?' London: Tavistock.

Miles, R., \& Satzewich, V. (1990). Migration, racism and "postmodern" capitalism. Economy and Society, 19, 3, 334-358.

Miles, R., \& Singer-Kérel, J. (1991). Introduction: Migration and migrants in France. Ethnic and Racial Studies, 14, 3, 265-278.

Naylon, J. (1987). Iberia. In H. Clout (Ed.), Regional development in western Europe, 3rd ed. London: Fulton, 383-418.

Newberry, B. (1994). Slums hide behind boom city. The European, 11-17 November.

Paterson, T., \& Payne, R. (1991). Race hate violence escalates. The European, 76, 2.

Pena Pires, R. (1987). Os retornados: Um estudo sociográfico. Lisboa: IED.

Pena Pires, R. (1990). O repatriamento de Africa: Enigmas e interrogações. In Actas do primeiro congresso Portugues de sociologia, a sociologia e a sociedade Portuguesa na viragem do século, Vol. II. Lisboa: Imprensa Fragmentos, 503520.

Pimpão, A (1991). Fconomia do Algarve: Preparar o terceiro milénio. Sociedade e Território, 13, 17-21.

Reis, T. C., \& Passos, C. (1991). Intervenção social nos bairros camarários de Lisboa. Sociedade e Território, 13, 102-108.

Rex, J. (1988). The ghetto and the underclass. Aldershot: Avebury.

Rosado, J. (1990). Girls enslaved by lure of jobs. The European, 13, 9.

Rosenbaum, M. (1992). Not so easy to love thy neighbour. The European, 113, 10.

Saint-Maurice, A., \& Guerra, I. (1988) Entre o ser e o sentir: A communidade caboverdiana em Portugal. Lisboa: IED.

Saint-Maurice, A., \& Pena Pires, R. (1989) Descolonização e migrações: Os imigrantes dos PALOP em Portugal. Revista Internacional de Estudos Africanos, 10 1, 203-226.

Sassen, S. (1988). The mobility of labour and capital: A study in international investment and labour flow. Cambridge: Cambridge University Press.

Sole, C. (1995). Racial discrimination against foreigners in Spain. New Community, $21,1,95-101$.

Sworder, M. (1994). Malnutrition and poverty affecting tens of thousands in Lisbon. Anglo-Portugese News, 17 March, 8. 
Wallis, H. (1986). Things hidden from other men: The Portugese voyages of discovery. History Today, 36, 27-33.

Webster, P. (1991). Deaths fuel race fears in France. The Guardian, 10 June.

Werth, M. (1989) L'immigration de ressortissants de pays tiers dans les états meridionaux de la communauté Européene: Résumé comparatif de la situation en Grèce, en Italie, en Espagne et au Portugal. Europe Sociale, 1/91, Luxembourg: CoECs.

Williams, S. (1992). Child labour in Portugal. London: Anti-Slavery International. Wise, P. (1990). Foreign cash powers a boom in Portugal. The European, 4, 20. 